\title{
Indigenous endomycorrhizal fungi at salak (Salacca zalacca) plantations in Bali, Indonesia and their colonization of the roots
}

\author{
I NYOMAN RAI ${ }^{1, \bullet}$, I KETUT SUADA ${ }^{1}$, MEITY W. PROBORINI ${ }^{2}$, I WAYAN WIRAATMAJA ${ }^{1}$, \\ MIKHAIL SEMENOV ${ }^{3}$, GEOGE KRASNOV $^{4}$ \\ ${ }^{1}$ Program of Agroecotechnology, Faculty of Agriculture, Universitas Udayana. Jl. Raya Kampus Unud, Bukit Jimbaran, Kuta Selatan, Badung 803611, \\ Bali, Indonesia. Tel./fax.: +62-361-702801, `email: rainyoman@unud.ac.id \\ ${ }^{2}$ Department of Biology, Faculty of Mathematics and Natural Sciences, Universitas Udayana. J1. Raya Kampus Unud, Bukit Jimbaran, Kuta Selatan, \\ Badung 803611, Bali, Indonesia \\ ${ }^{3}$ Dokuchaev Soil Science Institute, Departement of Soil Biology and Biochemistry, Moscow, Russia \\ ${ }^{4}$ Engelhardt Institute of Molecular Biology, Russian Academy of Sciences, Moscow, Rusia.
}

Manuscript received: 31 May 2019. Revision accepted: 31 July 2019.

\begin{abstract}
Rai IN, Suada IK, Proborini M, Wiraatmaja IW, Semenov M, Krasnov G. 2019. Indigenous endomycorrhizal fungi at salak (Salacca zalacca) plantations in Bali, Indonesia and their colonization of the roots. Biodiversitas 20: 2410-2416. Cultivation of snake fruit, commonly known as salak usually done organically on dry land with limited fertilizer in Bali. This research aimed to observe and to identify the indigenous endomycorrhizal fungi on salak roots. The exploration was carried out by collecting soil and root samples in salak producing areas in Bali, i.e. Bebandem and Selat of Karangasem Regency, Payangan of Gianyar, and Pupuan of Tabanan Regency. At each location, 9 random samples were taken, resulting in a total of 36 samples. Spore extraction was carried out using a wet filtration technique followed by centrifugation according to the method by Brunndrett et al. (2009). Morphological identification was carried out at the genus and species level using the Manual for Identification of Mycorrhiza Fungi for identifying Vesicular-Arbuscular-Mycorrhiza (VAM) fungi (Schenk and Perez, 1990), while molecular identification was carried out according to Tedersoo et al. (2014). The percentage of root infections was carried out using the coloring method with trypan blue. The results showed there were only two genera of endomycorrhizae (Glomus and Entrophospora) identified at the locations of study sites. The results also showed that samples from Bebandem and Selat regions had 3 Glomus species, Payangan had 3 Glomus species and 1 Entrophospora species, while in Pupuan had only 2 Glomus species. Identification results based on morphological characters showed that all species in the genus Glomus consisted of 3 species, namely Glomus sp-1, Glomus sp-2, and Glomus sp-3, while one species in the genus Entrophospora was Entrophospora sp. Genetic identification results based on the nucleotide arrangement showed that Glomus sp-1 concluded as Glomus cubence, Glomus sp-2 concluded as Glomus custos, and Glomus sp-3 concluded as Glomus indicum, while Entrophospora species concluded as Entrophospora_sp_SH197095.06FU. The average of root colonization/ infection was very high, reaching 93.33\% in Bebandem and Selat, $95.00 \%$ in Pupuan, and 100\% in Payangan. The very high root infection rates indicated that the indigenous endomycorrhiza found in these areas was very adaptive in salak plantation, so there is an opportunity to be developed as biofertilizers.
\end{abstract}

Keywords: Genetics, indigenous endomycorrhiza, infection rates, morphology, spores

\section{INTRODUCTION}

Snake fruit (Salacca zalacca) known as salak in Indonesia is a species of the palm tree (family Arecaceae) which is organically cultivated on dry land with limited production inputs in Bali. It is usually fertilized with leaf litters or other organic fertilizers with a minimum application and erratic administration time (Sukewijaya et al. 2009). This pattern was carried out by snake fruit farmers is due to the difficulty in obtaining adequate fertilizer. Therefore, soil fertility of salak plantations is usually low, and according to Rai et al. (2010), it is indicated by the low levels of C-organic and NPK in soil and leaf tissue. Endomycorrhizal fungal biofertilizers are being developed using isolates from the salak root area to overcome low fertility in salak plantations. The diversity of endomycorrhizal fungi, also known as VesicularArbuscular Mycorrhizal (MVA) fungi, is very large (Hempel et al. 2007; Wang and Yong Shi 2008; Avio et al. 2009; Baslam et al. 2011; Proborini 2013; Suamba et al.
2014; Sarah and Ibrar 2016; Choosa-nga et al. 2019), and the application in salak plantation has a positive effect on salak production (Juliadewi et al. 2014; Rai et al. 2015).

Research conducted by Rai et al. (2015) showed an increase in the production of salak Gula Pasir that fertilized with mycorrhizal biofertilizer, as well as producing offseason fruits which are caused by increased soil fertility, photosynthesis, total sugar content, $\mathrm{N}, \mathrm{P}, \mathrm{K}$, and $\mathrm{Mg}$ in leaf tissue. Rai et al. (2015) also stated that biofertilizer had a positive correlation with the length and breadth of the root in terms of coverage, so it absorbed more water and nutrients. Juliadewi et al. (2014) reported that the use of microfluidic biofertilizers up to $75 \mathrm{~g}$ per tree increased salak production as well as off-season production due to the increment in fruit set.

Mycorrhizae is a fungus that lives in a symbiotic relationship with spermatophytes. It colonizes the host's roots to create a mutually beneficial relationship without causing any harm. According to Menge (1985), Finlay (2008), Hernadi et al. (2012), and Zasvari et al. (2012), the 
hosts obtain nutrients and water from mycorrhiza, while the fungi, in turn, obtain carbohydrates or nutrition from the hosts. Smith and Read (2008), Lee et al. (2012), and Yinan et al. (2017) reported that mycorrhizae enhance plant growth because it increases its ability to obtain water and nutrients such as phosphorus, nitrogen, and potassium. In addition, mycorrhiza is capable of increasing host resistance to root pathogens (Pozo et al. 2010), increasing host tolerance to environmental stress due to salinity and drought (Latef et al. 2016; Quiroga et al. 2017), and heavy metal contamination (Upadhyaya et al. 2010). Moreover, mycorrhizal abundance and activities in the soil rhizosphere are largely determined by climate, host type, and soil water content or drought level (Schubler et al. 2001; Moreira et al. 2007; Hernadi 2012; Sadhana 2014; Quiroga et al. 2017; Mathimaran et al. 2017; Choosa-nga et al. 2019), type and level of soil fertility, as well as altitude (Allen and Boosalis, 1983; Tahat and Sijam 2012; Kavitha and Nelson 2013; Mo et al . 2016).

Based on the infection method, mycorrhizae are divided into two groups-ectomycorrhiza and endomycorrhiza. The ectomycorrhiza infects the outer surface of the roots and the tips, which then forms a white braid of hyphae/mycelia on the root hairs (Hartig's nets). This infection causes changes in the morphology of the root-shortening, swelling, dichotomous branching, and pigment formation. According to Smith and Read (2008), Finlay (2008), and Brundrett (2009), the hosts of ectomycorrhizae are generally forestry plants. However, endomycorrhiza infects the inside and between the cells of root tips. The hyphae from outside the roots enter the cell and fill the intercellular spaces, thereby forming arbuscles-hyphae tissues that penetrate the cells through plasmalemma and vesiclessmall bubbles like granules in the cytoplasm that contain lipids and useful for vegetative reproduction. Infections of endomycorrhiza form external hyphae, help to expand the space covered by the roots for absorbing nutrients. Endomycorrhizal infection does not change the morphology of the roots but changes the appearance of its cells and tissues. According to Schenck and Perez, (1990); Aguilar and Barea (1997); Hempel et al. (2007); Smith and Read (2008) \& Brundrett (2009), majority of these hosts are important agricultural commodities and seasonal crops like beans, rice, corn; horticulture plants like fruits, vegetables, and ornamental plants; and industrial plants like cocoa, rubber, coffee, cashew, etc. Based on their characteristics, the development of the mycorrhizal biofertilizer for agriculture predominantly uses endomycorrhizal fungi (Wang and Yong Shi 2008; Sadhana 2014).

Currently, there is ready-to-use mycorrhizal biological fertilizer in the form of powder, granules, and pellets. But according to Brundrett (2009) and Jha and Kumar (2011), the indigenous (local) mycorrhizae is more adaptive and efficient because its hyphae/mycelium and indigenous fungal spores have faster and better optimal adaptability in colonizing the root system of the host plant. This research is conducted to explore, and to identify the indigenous fungi from salak roots from several regions in Bali and to determine the potential of indigenous endomycorrhizae as biological fertilizer and their potential in colonizing roots.

\section{MATERIALS AND METHODS}

\section{Sampling locations}

The soil and root samples were taken from salak plantations in 4 locations in Bali (Bebandem and Selat of Karangasem Regency, Payangan of Gianyar Regency, and Pupuan of Tabanan Regency). Bebandem and Selat are the two major producers of salak in Bali were located in the eastern of Bali Island, while Payangan and Pupuan were located in the central and western of Bali.

\section{Roots and soil sampling}

Soil and root samples were taken from nine points at each location, and there were 36 samples in total. Soil samples were taken from the rhizosphere around the base of the bark. Samples were taken 30-40 cm around the base of the stem and at a depth of $10-15 \mathrm{~cm}$ from the ground surface to collect about $2 \mathrm{~kg}$ of soil (Chaurasia and Khare 2005; Nurhandayani et al. 2013). Root samples $(10 \mathrm{~cm})$ were taken from the same points were put into polyethylene bags and stored at $4^{\circ} \mathrm{C}$ in the laboratory. The level of the endomycorrhizal infection was observed as soon as the sample arrived in the laboratory.

\section{Extraction and isolation of spores}

The spore extraction was carried out using a wet filter technique followed by centrifugation according to the method by Brunndret et al. (2009). Exactly $100 \mathrm{~g}$ of soil samples was dissolved and evenly stirred in 1000-1200 mL of water, then sieved with a multi level sieves sized of 1 $\mathrm{mm}, 500 \mu \mathrm{m}, 212 \mu \mathrm{m}, 106 \mu \mathrm{m}$, and $53 \mu \mathrm{m}$. Dissolution and sieving were repeated 2-3 times, and the remaining soil was poured into the top filter. The top sieve was sprayed with water to facilitate the sieving and filtering process carried out from one sieve size to another. The filtered soil in the $500 \mu \mathrm{m}, 212 \mu \mathrm{m}$, and $53 \mu \mathrm{m}$ sieves were transferred to the centrifuge tube, then $25-40 \mathrm{~mL}$ of distilled water was added and centrifuged at a speed of $2000 \mathrm{rpm}$ for 5 minutes. The supernatant was removed and the pellets resuspended with $60 \%$ glucose and centrifuged again at a speed of $2000 \mathrm{rpm}$ for 1 minute. The supernatant containing sugar in each sieve was rinsed with water using a $53 \mu \mathrm{m}$ diameter filter. The results of the rinsing were placed in Petri dishes, and the spores were isolated and examined using a stereomicroscope (Zeiss Stemi 508).

\section{Morphology and genetic identification of indigenous endomycorrhizae}

The isolated spores were placed on microscope slide added with a drop of polyvinyl alcohol-lactic-glycerol acid (PVLG), to identify indigenous endomycorrhizae based on their morphology with the use of a compound microscope (Zeiss Axioscope 40) at 10 and 100x magnification. The morphological identification was carried out at the genus and species level using the Manual for Identification of Mycorrhiza Fungi for identifying Vesicular-ArbuscularMycorrhiza (VAM) fungi (Schenk and Perez, 1990), based on characteristics of size, color, spore arrangement, shape, hyphae attachment, and the number of spore walls. The results were compared with various libraries and an online 
database description of mycorrhizal species at West Virginia University, USA (http: //invam.caf.wvu.edu).

The molecular identification was carried out according to the method by Tedersoo et al. (2014). Total DNA was extracted using MagNA Pure Compact Nucleic Acid Isolation Kit I (Roche) based on the manufacturer's instructions. The analysis of the cells and tissues was performed using MagNA Pure Bacteria Lysis Buffer (Bacteria, Fungi) (Roche). Extracted DNA samples were stored at $-20{ }^{\circ} \mathrm{C}$ for further analysis. The amplicon libraries of the ITS5F-ITS4 regions were prepared following the procedure of Illumina Metagenomic. The fragments of the ITS region were amplified using the forward primer ITS-5 F (5' GGAAGTAAAAGTCGTAACAAGG 3') and the reverse primer ITS-4 (5, TCCTCCGCTTATTGATATGC 3'). The PCR was performed using Tersus PCR kit (Evrogen, Russia) based on the manufacturer's instructions.

\section{Observation of root colonization/infection}

The level of root infection by indigenous endomycorrhiza was observed using slide method according to Giovannetti and Mosse (1980) with the formula as follows:

Percentage of infected roots $=$ number of infected roots: total number of roots observed $\mathrm{x} 100 \%$.

Root infection rates are classified into 5 classes; which are very low (0-5\%), low (6-25\%), moderate (26-50\%), high $(51-75 \%)$ and very high (76-100\%). Observation of root infection was conducted by trypan blue staining assay. The staining process began by washing the roots and then cutting the clean roots into $2-5 \mathrm{~cm}$, after which $20-30$ pieces were inserted into the test tube and soaked in $10 \%$ $\mathrm{KOH}$ and heated in a microwave at $250^{\circ} \mathrm{C}$ for 10 minutes. Heated roots were left for \pm 12 hours at room temperature. After that, $10 \% \mathrm{KOH}$ solution was removed, and the roots were washed 3 times with water. Roots were then soaked in $3 \% \mathrm{H}_{2} \mathrm{O}_{2}$ and stored for \pm 12 hours at room temperature. After finish storing, $\mathrm{H}_{2} \mathrm{O}_{2}$ was removed and the roots were washed 3 times with water, soaked in $1 \% \mathrm{HCL}$, and stored for \pm 12 hours at room temperature. $\mathrm{HCl}$ was removed, and the roots were immersed in trypan blue, and then heated at $250{ }^{\circ} \mathrm{C}$ for 5 minutes in a microwave and stored for \pm 12 hours at room temperature, then trypan blue was removed, and the roots were soaked in lactoglycerol and heated at $250{ }^{\circ} \mathrm{C}$ for 5 minutes. The roots were then stored \pm 12 hours at room temperature. After the administration of lactoglycerol was completed, the roots were then taken with tweezers and placed lined up on a glass object for observation using a microscope to determine the existence of infection and structure of mycorrhizae (vesicles, arbuscular, hyphae).

\section{RESULTS AND DISCUSSION}

\section{Species diversity and spore density}

The results in Table 1 showed that soil samples from Bebandem and Selat only have 3 species of endomycorrhizae that belongs to the Glomus genus.
Isolation of endomycorrhizae from Payangan soil sample showed 3 species, 2 species belonging to the Glomus genus and one species from the genus Entrophospora, while the Pupuan sample has 2 species, both in the Glomus genus. The results of the spores identification showed that endomycorrhizae from the study sites were included in 2 genera, namely Glomus and Entrophospora. Glomus genus was found in all sampling locations, while Entrophospora was only found in Payangan. According to INVAM (2014), Glomus and Entrophospora were both belong to the Zygomycota phylum, the order of Glomeromycota and Glomineae sub-order. The difference between the two is that Glomus belongs to the Glomaceae family, while Entrophospora belongs to the family Entrophosporaceae.

The density of spores of the soil samples taken from the four sub-districts ranging from 13 to 30 spores per $100 \mathrm{~g}$ of soil (average 20.06 \pm 5.57 spores). Different locations have different spore densities $(\mathrm{P}<0.05)$ with the highest spores density was in the salak roots from Pupuan (27.11 2 2.76 spores), which was significantly different from spores density obtained from the three other sub-districts. The lowest spore density was obtained from soil samples collected in Bebandem (15.44 \pm 2.70 spores), but it did not significantly different from that of Selat $(15,78 \pm 2,95$ spores) (Table 1).

\section{Morphology and genetic identification of spores}

Spores identification was based on characters such as size, color, the arrangement of spores, hyphae shape and attachment, and several spore walls. The results showed that all Glomus species collected from four locations consist of only 3 species-Glomus sp-1, Glomus $s p-2$ and Glomus sp-3, as shown in figures $1 \mathrm{~A}, 1 \mathrm{~B}$, and 1C, while one species in the Entrophospora genus was identified as Entrophospora $s p$ as shown in Figure 1D. Glomus $s p-1$ is morphologically similar to Glomus cubense (Roddigues et al. 2011) and Glomus ambisporum (INVAM 2014), as shown in figures $2 \mathrm{~A}$ and $2 \mathrm{~B}$, Glomus $s p-2$ is similar to Glomus custos (Cano et al. 2009) and Glomus hoi (INVAM 2014), as shown in figures $2 \mathrm{C}$ and 2D. Glomus $s p-3$ is similar to Glomus indicum (Blaszkowski et al. 2010) and Glomus pansiholus (INVAM 2014), as shown in figures $2 \mathrm{E}$ and $2 \mathrm{~F}$.

Table 1. Spore density, genus, and number of indigenous endomycorrhizal species in salak samples from four different locations

\begin{tabular}{lcccc}
\hline Sub-district & Bebandem & Selat & Payangan & Pupuan \\
\hline Genus & Glomus & Glomus & $\begin{array}{c}\text { Glomus and } \\
\text { Entropohospora }\end{array}$ & Glomus \\
Species & 3 & 3 & 4 & 2 \\
$\begin{array}{l}\text { Spore density } \\
(\%)\end{array}$ & $15.44 \pm 2.70 \mathrm{c}$ & $15.78 \pm 2.95 \mathrm{c}$ & $21.89 \pm 2.68 \mathrm{~b}$ & $27.11 \pm 2.76 \mathrm{a}$ \\
\hline
\end{tabular}

Note: In the spore density row, the numbers followed by the same letter mean that there is no significant difference in the LSD test level of $5 \%(\mathrm{~T}$ value $=1.80)$ 

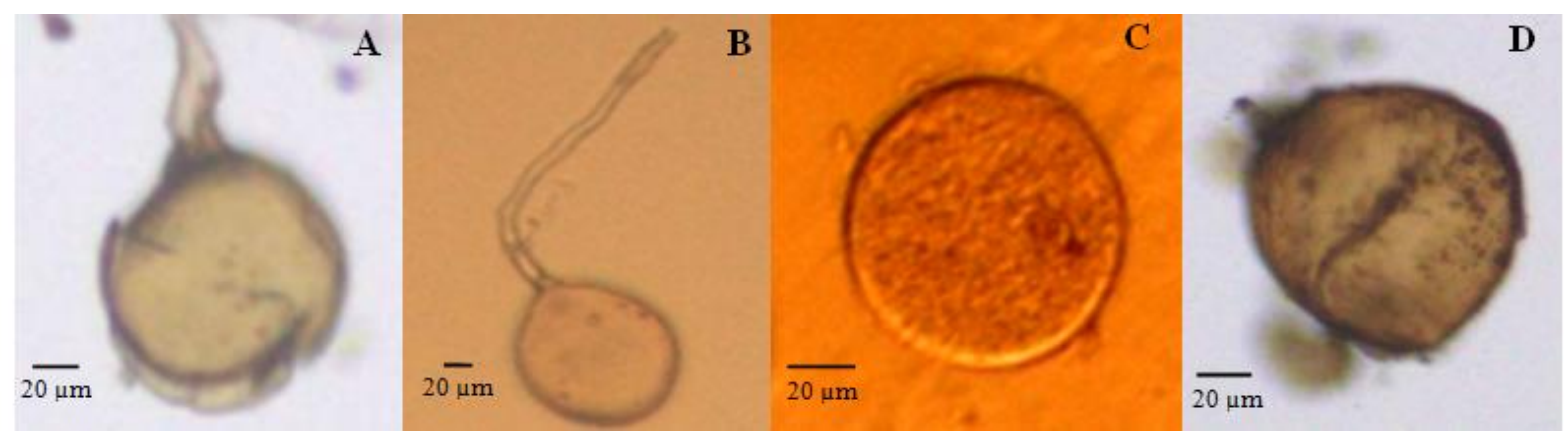

Figure 1. Three Species of Endomychorrizae isolated from salak roots. Two isolates belongs to the genus of the Glomus and one species of Entrophospora. Glomus sp-1 (A), Glomus sp-2 (B), and Glomus sp-3 (C), and Entrophospora sp. (D)

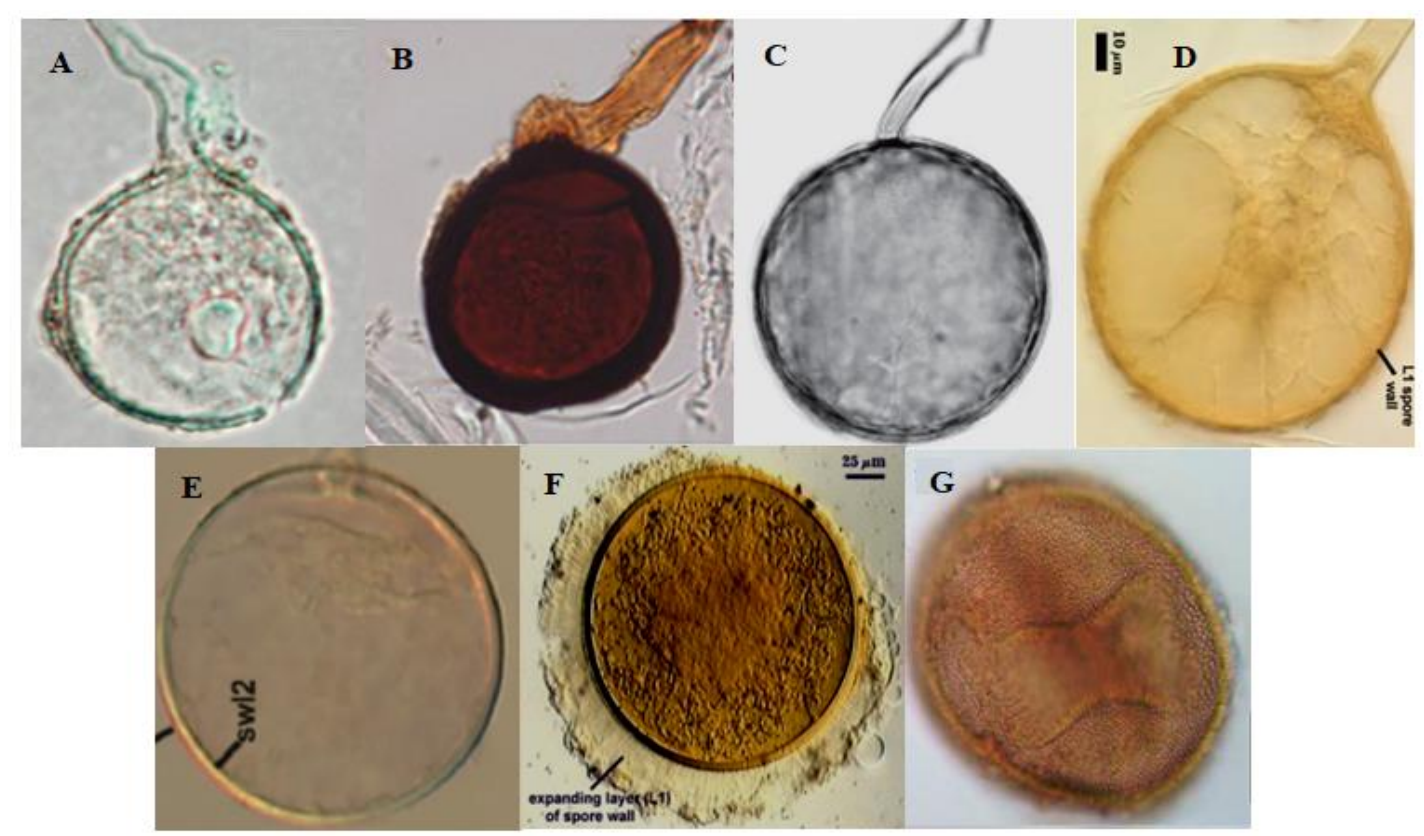

Figure 2. The indigenous endomycorrhiza isolate from roots of salak were similar to Glomus and Entropospora species in the library. Glomus cubense (Roddigues et al. 2011) (A) and Glomus ambisporum (INVAM 2014) (B) are similar to Glomus sp-1 (1A), Glomus custos (Cano et al. 2009) (C) and Glomus hoi (INVAM 2014) (D) similar to Glomus sp-2 (1B), Glomus indicum (Blaszkowski et al. 2010) (E) and Glomus pansiholus (INVAM 2014) (F) similar to Glomus sp-3 (1C), and Entrophospore infrequent (Hernandes et al. 2018) (G) similar to Entrophospore sp. (1D)

Morphologically Glomus sp- 1 has the characteristics of a sporocarp, round spores, $50-80 \mu \mathrm{m}$, yellow/brownish yellow or dark brown, the surface of the spores was varies (rough and smooth), and there were hyphae attach to the spore wall. Morphological characteristics of Glomus sp-2 are single and oval spores, 75-120 $\mu \mathrm{m}$, light brown, smooth spore surfaces, hyphae that were still attached to spores and spore walls consisting of two separate layers. While the morphological characteristics of Glomus $s p$-3 were single spheres, round, 108-180 $\mu \mathrm{m}$, golden yellow, the surface of the spore is slightly rough, and has sub standing hyphae. According to INVAM (2014), Glomus spores can be single or in groups. According to Sastrahidayat (2011), Glomus genus has a single or double spore wall and is equipped with oily spots on mature spores of varying sizes, the surface of the smooth spore wall has no ornament, and has cylindrical straight, subtending hyphae. Glomus spores were formed from enlargement of hyphae to the maximal size, which eventually forms spores. The presence of hyphae which always attach to the spore wall consisted of 1-3 spore walls is a typical characteristic of Glomus spore. The branches of hyphae form a sporocarp (clustered spores).

The morphological features of Entrophospora sp. found in salak roots obtained from Payangan are elliptical, yellow or yellowish red, and the spore walls are not clear, as shown in Figure 1D. The outer appearance of the Entrophospora sp. is similar to Entrophospora infrequent (Hernandes et al. 2018) (Figure 2G). According to Oehl et al. (2011) and INVAM (2014), Entrophospora is a mycorrhizal genus belonging to the family Entrophosporaceae, having 2-3 spore walls, spores formed on the side of the soporiferous neck, round to elliptical, yellow or yellowish red, and $100-400 \mu \mathrm{m}$. 
Genetic identification based on the nucleotide arrangement showed that Glomus sp-1 concluded as Glomus cubense, Glomus sp-2 concluded as Glomus custos, and Glomus sp-3 concluded as Glomus indicum, while the Entrophospora genetically concluded as Entrophospora_sp_SH197095.06FU. All the Glomus species found in this study, i.e. Glomus cubense, Glomus custos, and Glomus indicum are categorized by INVAM (2014) as new species. The nucleotide arrangement of indigenous endomycoriza species found in the salak root in Bali are as follows:

1. Glomus cubense. >@M05275: 83: 000000000-BGVKJ: 1: 1111: 18969: 24571 [confidence $=0.98$ ].

TCTCCGTTGGTGAACCAGCGGAGGGATCATTACAGA GTTGCAAAACTCCCAACCATTGTGAACGAACCCGTT ATAGTTGCTTCGGCGGGGGGTGCGCTGCAACCACCC GCCGGCAGCATGCAAACTCTAGATTATAGTGGATCT CTGAGTAGCTTATTTAATAAGTCAAAACTTTCAACA ACGGATCTCTTGGTTCTGGCATCGATGAAGAACGCA GCGAAATGCGATANNNNNNNNNNNNNNNTAGTATT CTGGCGGGCATGCCTGTTCGGGCGTCATTTCAACCAT CAGCCCCTGTCTAGGTCTGTGTTGGGGGCCTGCGCCT GCCGCAGCCCCCTAAATGCAGTGGCGGGCTCGCTGT TACCCCGAGCGCAGTAGTGTATCTCGCTCTGGGCGT GGCAGCGGGTGCTAGCCGTGAAACACTCACTAAGGT TGACCTCGGATCAGGTAGGAATACCCGCTGAACTTA A.

2. Glomus custos. >@M05275: 83: 000000000-BGVKJ: 1: 1106: 15949: 15504 [confidence $=1$ ].

TCTCCGTTGGTGAACCAGCGGAGGGATCATTACCGA GTTTTCAACTCCCAAACCCCTGTGAACATACCATTTT GTTGCCTCGGCGGTGCCTGTTCCGACAGCCCGCCAG AGGACCCCAAACCCAAATTTCCTTGAGTGAGTCTTCT GAGTAACCGATTAAATAAATCAAAACTTTCAACAAC GGATCTCTTGGTTCTGGCATCGATGAAGAACGCAGC GAAATGCGATANNNNNNNNNNNNNNNGGCGGCCTT GCCTGGTCGGGCGTCATTTCAACCCCCAAGCCCCCG GGCTTGGTGTTGGGGATCGGCGAGCCTCTGCGCCCG CCGTCCCCTAAATTGAGTGGCGGTCACGTTGTAACTT CCTCTGCGTAGTAGCACACTTAGCACTGGGAAACAG CGCGGCCACGCCGTAAAACCCCCAACTTTTGAACGT TTGACCTCGAATCAGGTAGGACTACCCGCTGAACTT AA.

3. Glomus indicum. >@M05275: 83: 000000000-BGVKJ: 1: 1105: 2880: 18372 [confidence $=0.99$ ].

TCTCCGTTGGTGAACCAGCGGAGGGATCATTACAGAG TTGCAAAACTCCCAACCATTGTGAACGAACCCGTTAT AGTTGCTTCGGCGGGGGGTGCGCTGCAACCACCCGCC GGCAGCATGCAAACTCTAGATTATAGTGGATCTCTGA GTAGCTTATTTAATAAGTCAAAACTTTCAACAACGGA TCTCTTGGTTCTGGCATCGATGAAGAACGCAGCGAAA TGCGATANNNNNNNNNNNNNNNTAGTATTCTGGCGG GCATGCCTGTTCGGGCGTCATTTCAACCATCAGCCCC TGTCTAGGTCTGTGTTGGGGGCCTGCGCCTGCCGCAG CCCCCTAAATGCAGTGGCGGGCTCGCTGTTACCCCGA GCGCAGTAGTGTATCTCGCTCTGGGCGTGGCAGCGGG TGCTAGCCGTGAAACACTCACTAAGGTTGACCTCGGA TCAGGTAGGAATACCCGCTGAACTTAA.

4. Entrophospora_sp_SH197095.06FU. >@M05275: 83: 000000000 BGVKJ: 1: 1106: 11344: 27377 [confidence = 1].

TCTCCGTTGGTGAACCAGCGGAGGGATCATTACAGA GTTGTAAAACTCCCAAACCCATGTGAACATACCTGT TGCCTCGGCGGCCTACCCGGCAGCTACCCTGTAGCT ACCCTGTAGTCCGCCGACGGATTTCAAAACTCTTGTT TCCAGTTGTATCTCTGAGAATAAAACAAATAAATCA
AAACTTTCAACAACGGATCTCTTGGTTCTGGNNNNN NNNNNNNNNNGTTCGAGCGTCATTAGGTCCACTTAA GCCCTGTTTAGTGTTGGGAGACTGCTCCGGGGGTGC TACCCTGTTGCTCCCCTGCAGCTCCTCAAAGACAGCG GCGGAGTTGTGGTATCCTCTGAGCTTAGTAACTTGTT CTATCTTTCGAGTACACCACTTCCCCTGCCGTAAAAC CCTTAATTTTTAATGGTTGACCTCGGATCAGGTAGGA ATACCCGCTGAACTTAA.

\section{Colonization/root infection by indigenous endomycorrhiza}

Based on the results, it showed that the average root colonization by the indigenous endomycorrhiza was high; i.e., 93.33\% in Bebandem and Selat, $95.00 \%$ in Pupuan, and $100 \%$ in Payangan as shown in Table 2. Although spore density was low (Table 1), the results proved that these indigenous endomycorrhizas were very adaptive in salak plants. It was indicated by a very high rate of infection and the ability to colonize roots with an average percentage of infections as high as $95.42 \%$. Therefore, with a high root infection rates, these indigenous endomycorrhizae have great potential to be developed as biological fertilizers. It was in accordance with Pulungan (2013) that indigenous endomycorrhizae which was classified as arbuscular mycorrhizal fungi can be used as an alternative technology to help growth and improve the quality and productivity of plants, especially in infertile marginal lands. According to Brundrett et al. (2009), the level of root infection by mycorrhiza is strongly influenced by the level of soil fertility. High infections occurred when the soil around the roots was infertile. Consequently, the high mycorrhizal root infection in this study was related to the low soil fertility in the salak plantation. It was also in accordance with the results of a study conducted by Rai et al. (2010) that the level of soil fertility and nutrient content of $\mathrm{N}, \mathrm{P}$, and $\mathrm{K}$ in the leaves tissue of salak plants in Karangasem Regency was relatively low.

The results of the study showed that the endomycorrhizae structure isolated from the cortical root cells of salak consisted of hyphae, spores, arbuscular, vesicles, and chlamydospores (Table 2). Hyphae were found along the root cortex with an almost straight shape (Figure 3A). In the root cortex, also found arbuscular hyphae (Figure 3B), vesicular hyphae (Figure 3C), internal hyphae (Figure 3D), and external hyphae (Figure 3E). The bubble tip is turned into a spore; therefore, the spores are formed from the swelling of the hyphae. According to Navarro et al. (2012), spores originating from the development of hyphae are called chlamydospore and in each branching hyphae are formed chlamydospore called sporocarp. Kehri et al. (2018), reported that indigenous endomycorrhizal fungi are arbuscular groups of mycorrhizae which always form vesicular and arbuscular in cortical cells. Puspitasari et al. (2012) reported that the genus Glomus has a high adaptation to environmental conditions so that they are mostly found in a symbiotic relationship with the roots of various types of plants. The result of this study was in accordance with Puspitasari et al. (2012) that the genus Glomus, presence in all sampling locations, hence, it is classified as a genus with very high adaptability. 
Table 2. Endomycorizal structure of Glomus Genus and Entrophospora Genus in Salak Root Cortex Cells in Four Sampling Locations

\begin{tabular}{llllllcll}
\hline \multirow{2}{*}{ Sub-districts } & \multicolumn{9}{c}{ Structure of endomycorrhiza } & \multicolumn{2}{c}{$\begin{array}{c}\text { Average root } \\
\text { infection (\%) }\end{array}$} \\
\cline { 2 - 6 } & H & S & A & V & Ks & Genus \\
\hline Bebandem & $(+)$ & $(+)$ & $(+)$ & $(+)$ & $(+)$ & 93.33 & Glomus \\
Selat & $(+)$ & $(+)$ & $(+)$ & $(+)$ & $(+)$ & & 93.33 & Glomus \\
Payangan & $(+)$ & $(+)$ & $(+)$ & $(+)$ & $(+)$ & & 100.00 & Glomus and Entrophospora \\
Pupuan & $(+)$ & $(+)$ & $(+)$ & $(+)$ & $(+)$ & & 95.00 & Glomus \\
\hline
\end{tabular}
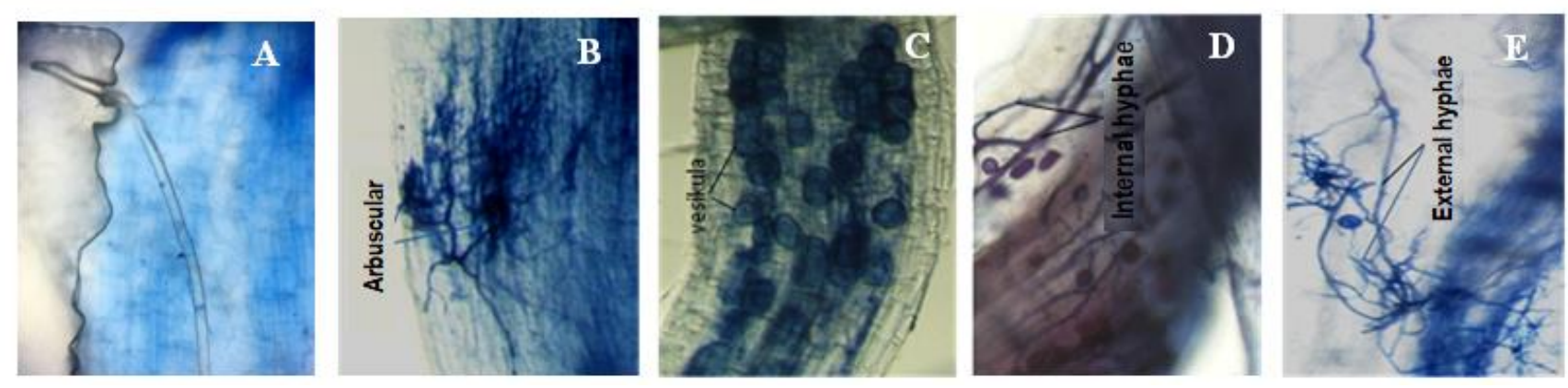

Figure 3. The structures of hyphae from endomycorrhiza in the cortical root cells of salak (A), arbuscular hyphae (B), Vascular Hyphae (C), Internal Hyphae (D), and External Hyphae (E). Note: : $\mathrm{H}=$ hyphae, $\mathrm{S}=$ spore, $\mathrm{A}=$ arbuscular, $\mathrm{V}=$ vesicular, Ks = clamidospora, and $(+)=$ endomycorhizza infection

According to Nusantara et al. (2012), and Kehri et al. (2018) external hyphae absorb phosphorus and water from the soil and brought to the internal and arbuscular hyphae for host plant growth, while internal hyphae absorb organic material from the host plants for mycorrhizal growth. Kavitha and Nelson (2013) reported that mycorrhizae grow from outside the root and then enters the root tissue and the arbuscular hyphae cells (tissue hyphae which penetrate between cells and penetrate cells through plasmalemma). In the cells, the hyphae form vesicles, small bubbles in the cytoplasm, granular vesicles containing lipids and become vegetative mycorrhizal reproductive cells. Arbuscular is hyphae which penetrate plasmalemma and help transport nutrients to plant cells.

In addition to vesicles and arbuscules, external hyphae are formed to help expand the nutrient absorption by the roots. In certain plants, the length of the external hyphae usually reaches $80 \mathrm{~cm}$ per $1 \mathrm{~cm}$ of root length. Outside the roots, hyphae can form sporangium which produces spores as a means of reproduction. The extent of hyphae tissue in the soil helps the roots absorb nutrients and water. In this study, the formation of vesicles and arbuscules in salak root cells showed perfect symbiosis so that the plants increase the availability of nutrients absorbed from the soil.

Based on the results, it is concluded that there were 2 endomycorrhizae genera, Glomus and Entrophospora, isolated from salak roots taken from 4 different locations in Bali. Glomus is a genus that has a large distribution area because it was found in all sampling locations, while Entrophospora has a limited distribution area. There were three isolates of the genus Glomus genus and one isolate of the genus Entropohospora isolated from the roots of salak.
Root infection rates are very high, reaching 100\%, indicating that indigenous endomycorrhizae are very suitable to be developed as biological fertilizers, but the population needs to be increased due to low population density.

\section{ACKNOWLEDGMENTS}

Our gratitude goes to the Directorate General of Higher Education, Ministry of Research, Technology and Higher Education for the funds provided through the Higher Education Applied Research (MP3EI) in 2018. The authors also thank the Russia-ASEAN Secretary Office for funding the molecular identification of mycorrhiza through a grant of Environmentally-Friendly Technologies of Agriculture: Problems and Prospects in 2018.

\section{REFERENCES}

Aguilar C, Barea, JM. 1997. Applying mycorrhiza biotechnology to horticulture: significance and potentials. Scientia Horticulturae 68 (1): $1-24$.

Allen MF, Boosalis MG. 1983. Effects of two species of VA mycorrhizal fungi on drought tolerance of winter wheat. New Phytol 93: 6776. DOI: $10.1111 /$ j.1469-8137.1983.tb02693.x.

Avio L, Cristani C, Strani P, Giovannetti M. 2009. Genetic and phenotypic diversity of geographically different isolates of glomus mosseae. Canadian J Microbiol 55: 242-253.

Baslam M, Garmendia I, Goicoechea N. 2011. Arbuscular mycorrhizal fungi (AMF) improved growth and nutritional quality of greenhousegrown lettuce. J Agric Food Chem 59 (10): 5504-5515.

Błaszkowski J, Wubet T, Harikumar VS, Ryszka P, Buscot F. 2010. Glomus indicum, A new arbuscular mycorrhizal fungus. Botany 88 : 
132-143. DOI: $10.1139 / \mathrm{B} 09-104$

Brundrett M. 2009. Mycorrhizal associations and other means of nutrition of vascular plants: understanding the global diversity of host plants by resolving conflicting information and developing reliable means of diagnosis. Plant Soil 320: 37-77.

Cano C, Bago A, Dalpe Y. 2009. Glomus custos sp. nov., isolated from a naturally heavy metal-polluted environment in southern Spain. Mycotaxon 109: 499-512. DOI: 10.5248/109.499

Chaurasia B, Khare PK. 2005. Host selection for mass production of arbuscular mycorrhizal fungi from natural soil. J Appl Ecol Environ Res 4 (1): 45-53.

Choosa-Nga P, Sangwanit U, Kaewgrajang T. 2019. The arbuscular mycorrhizal fungi's diversity in fabaceous trees species of Northeastern Thailand. Biodiversitas 20 (2): 405-412. DOI: 10.13057/biodiv/d200214.

Finlay RD. 2008. Ecological aspects of mycorrhizal symbiosis: with special emphasis on the functional diversity of interactions involving the extraradical mycelium. J Experimental Botany 5 (5): 1115-1126.

Giovannetti M, Mosse B. 1980. An evaluation of techniques for measuring vesicular arbuscular mycorrhizal infection in roots. New Phytologist 84: 489-500. DOI: 10.1111/j.1469-8137.1980.tb04556.x.

Hempel S, Renker G, Buscot F. 2007. Differences in the species composition of arbuscular mycorrhizal fungi in spore, root and soil communities in a grassland ecosystem. Environ Microbiol 9: 19301938.

Hernandes SC, Cuevas LVH, Montaño NM, Cerrato RF, Alarcon A. 2018 Species composition of native arbuscular mycorrhizal funga consortia influences growth and nutrition of Poblano pepper plants (Capsicum annuum L.). Appl Soil Ecol 130: 50-58. DOI: 10.1016/j.apsoil.2018.05.022.

Hernadi P, Sasvari Z, Albrechtova J, Vosatka M, Posta K. 2012. Arbuscular mycorrhizal inoculants increase yield of spice pepper and affects indigenous fungal community in the field. Hort Science 47 (5): 603-606.

INVAM (International Culture Collection of Vesicula Arbuscula Mycorrhizal Fungi). 2014. Taxonomy. http://invam.caf. wvu.edu/Myc_Info [Accesed 26 Juni 2014)

Jha S, Kumar KN. 2011. Potential of mycorrhizal fungi in ecosystem: A Review. Intl J Res Bot 1 (1): 1-7

Juliadewi KAC, Rai IN, Kartini NL. 2014. Application of endomychorrizal fungal dose to increase production of snake fruit $\mathrm{cv}$. Gula Pasir. J Plumula 4 (3): 19-25. [Indonesian]

Kavitha T, Nelson R. 2013. Diversity of arbuskular mycorrhizal fungi (AMF) in the rhizophere of Helianthus annuus L. American-Eurasian J Agric Environ Sci 13 (7): 982-987.

Kehri HK, Akhtar O, Zoomi I, Pandey D. 2018. Arbuscular mycorrhizal fungi: taxonomy and its systematics. Intl J Life Sci Res 6 (4): 58-71.

Latef AAHA, Hashem A, Rasool S, Abd_Allah EF , Alqarawi AA Egamberdieva D, Jan S, Anjum NA, Ahmad P. 2016. Arbuscular mycorrhizal symbiosis and abiotic stress in plants: a review. J Plant Biol 59: 407-426. DOI: 10.1007/s12374-016-0237-7.

Lee BR, Muneer S, Avice JC, Jin Jung W, Kim TH. 2012. Mycorrhizal colonisation and $\mathrm{P}$-supplement effects on $\mathrm{N}$ uptake and $\mathrm{N}$ assimilation in perennial ryegrass under well-watered and drought-stressed conditions. Mycorrhiza 22: 525-534.

Mathimaran N, Sharma MP, Raju MB, Bagyaraj DJ. 2017. Mycosphere essay 17 arbuscular mycorrhizal symbiosis and drought tolerance in crop plants. Mycosphere 8 (3): 361-376. DOI 10.5943/mycosphere/8/3/2.

Menge JA. 1985. Effect of soil fumigants and fungicides on vesicular arbuscular fungi. Phytopathol 72: 1125-1132.

Mo Y, Wang Y, Yang R, Zheng J, Liu C, Li H, Ma J, Zhang Y, Wei C, Zhang X. 2016. Regulation of plant growth, photosynthesis, antioxidation and osmosis by an arbuscular mycorrhizal fungus in watermelon seedlings under well-watered and drought conditions. Front Plant Sci 7: 644. DOI: 10.3389/fpls.2016.00644

Moreira S, Dilmar M, Tsai SM. 2007. Biodiversity and distribution of arbuscular mycorrhizal fungi in Araucaria angustifolia forest. J Agric 64 (2): 393-399.

Navarro AM, Moragues JGS, Banuet AV, Verdu M. 2012. The network structure of plant-arbuscular mycorrhizal fungi. New Phytol 194: 536-547. DOI: 10.1111/j.1469-8137.2011.04045.x

Nurhandayani R, Linda R, Khotimah S. 2013. Inventory of arbuscular vesicular mycorrhizal fungi from rhizosphere of pineapple (Ananas comosus L. Merr) in peat soils. J Protobiont 2 (3): 146-151. [Indonesian]
Nusantara AD, Bertham YH, Mansur I. 2012. Working with arbuscular mycorrhizal fungi. Southeast Asian Regional Centre for Tropical Biology. First Print: November 2012. Bogor Agricultural University, Bogor. [Indonesian]

Oehl F, Sieverding E, Palenzuela J, Ineichen K. 2011. Advances in glomeromycota taxonomy and classification. Intl Mycol Assoc Fungus 2 (2): 191-199. DOI: 10.5598/imafungus.2011.02.02.10.

Pozo, MJ, Jung SC, Lopez-Raez JA, Azcon-Aguilar C. 2010. Impact of arbuscular mycorrhizal symbiosis on plant response to biotic stress: the role of plant defence mechanisms. In: Koltai H, Kapulnik Y. (eds.). Arbuscular Mycorrhizas: Physiology and Function. Springer, New York.

Proborini MW, Sudana M, Suarna W, Ristiati P. 2013. Indigenus vesicular arbuscular mycorrhizal (VAM) fungi in cashew nut (Anacardium occidentale L.) plantation of North East Bali Island-Indonesia. J Biol Agric Healthcare 3 (3): 114-121.

Puspitasari D, Purwani KI, Muhibuddin A. 2012. Exploration of indigenous vesicular arbuscular mycorrhiza (VAM) in corn in Torjun Village, Sampang Madura. J Sci Art 1: 19-22. [Indonesian]

Quiroga G, Erice G, Aroca R, Chaumont F, Ruiz-Lozano JM. 2017. Enhanced drought stress tolerance by the arbuscular mycorrhizal symbiosis in a drought-sensitive maize cultivar is related to a broader and differential regulation of host plant aquaporins than in a droughttolerant cultivar. Front Plant Sci 8: 1056. DOI: 10.3389/fpls.2017.01056.

Rai IN, Semarajaya CGA, Wiraatmaja IW. 2010. A Study on the flowering phenophysiology of snake fruit cv. Gula Pasir to prevent failure of fruit-set. J Hort 20 (3): 216-222.

Rai IN, Wiraatmaja IW, Semarajaya CGA, Alit Astiari NK, Astawa NG. 2015. Application of mycorhiza arbuscular dosage and organic fertilizer to produce off-season fruit of snake fruit cv. Gula Pasir (Salacca zalacca var. Gulapasir). Article Presented on International Conference of Bioscience and Biotechnology. Udayana University, September 18-19th, 2015.

Rodriguez Y, Dalpe Y, Seguin S, Fernandez K, Fernandez F, Rivera RA. 2011. Glomus cubense sp. nov., an arbuscular mycorrhizal fungus from Cuba. Mycotaxon 118: 337-347. DOI: 10.5248/118.337

Sadhana B. 2014. Arbuscular mycorrhizal fungi (AMF) as a biofertilizer: a review. Intl J Curr Microbiol Appl Sci 3 (4): 384-400.

Sastrahidayat IR. 2011. Method for making mycorrhizal biofertilizers to increase agricultural production. Brawijaya University Press, Malang, East Java. [Indonesian]

Sarah S, Ibrar M. 2016. Effects of arbuscular mycorrhizal fungi on spores density and root colonization of four hybrids of sunflower (Helianthus annuus L.) at different rock phosphate levels. Sarhad J Agric 32 (4): 258-266. DOI: 10.17582/journal.sja/2016.32.4.258.266.

Sasvari Z, Magurno1 F, Galanics D, Nhu Hang TT, Hong Ha TT, Luyen ND, Huong LM, Posta K. 2012. Isolation and identification of arbuscular mycorrhizal fungi from agricultural fields of Vietnam. Amer J Plant Sci 3: 1796-1801

Schenck NC, Perez Y. 1990. Manual for the Identification of V. A. Mycorrhizal (VAM) fungi. University of Florida Press, Florida, USA.

Schubler A, Schwarzott D, Walker C. 2001. A new fungal phylum, the glomeromycota: phylogeny and evolution. Trop Ecol 44 (2): 207-215.

Smith SE, Read DJ. 2008. Mycorrhizal symbiosis. 3rd ed. Academic Press. Elsevier Ltd. New York.

Suamba IW, Wirawan IGP, Adiartayasa W. 2014. Isolation and identification of arbuscular mycorrhiza fungi at citrus (Citrus sp.) rizosphere in Kerta Village, Payangan District, Gianyar Regency microscopically. E-Journal Trop Agroecotechnol 3 (4): 201-208.

Sukewijaya IM, Rai IN, Mahendra MS. 2009. Development of salak bali as an organic fruit. Asian J Food Agro-Industry. Special Issue: 37-43.

Tahat MM, Sijam K. 2012. Mycorrhizal fungi and abiotic environmental conditions relationship. Res J Enveron Sci 25: 431-440. DOI: 10.3923./rjes.2012.

Tedersoo L, Bahram M, Polme S, et al. 2014. Global diversity and geography of soil fungi. Science 346 (6213): 1078. DOI: 10.1126/science. 1256688 .

Upadhyaya H, Panda SK, Bhattacharjee MK, Dutta S. 2010. Role of arbuscular mycorrhiza in heavy metal tolerance in plants: prospects for phytoremidiation. J Phytol 2 (7): 16-27.

Yinan Z, Hongqing YU, Tao Z, Jixun G. 2017. Mycorrhizal colonization of chenopods and its influencing factors in different saline habitats, China. J Arid Land 9 (1): 143-152. DOI: 10.1007/s40333-016-0027-6.

Wang FY, Yong Shi Z. 2008. Biodiversity of arbuscular mycorrhizal fungi in china: a review. Adv Environ Biol 2 (1): 31-39. 
BIODIVERSITAS

Volume 20, Number 8, August 2019

Pages: 2410-2416
ISSN: 1412-033X

E-ISSN: 2085-4722

DOI: $10.13057 /$ biodiv/d200840 